\section{Silicon-based Fertilizer Applications Have No Effect on the Reproduction and Development of the Citrus Mealybug, Planococcus citri Risso (Hemiptera: Pseudococcidae), Feeding on Fiddleleaf Fig, Ficus lyrata (Warb.)}

Brian K. Hogendorp

University of Illinois, Department of Natural Resources and Environmental Sciences, Urbana, IL 61801

Raymond A. Cloyd ${ }^{1}$

Kansas State University, Department of Entomology, 123 Waters Hall, Manhattan, KS 66506-4004

John M. Swiader

University of Illinois, Department of Natural Resources and Environmental Sciences, Urbana, IL 61801

Additional index words. pest management, interiorscapes, silicon, greenhouse, horticulture, potassium silicate

Abstract. Mealybugs are major insect pests of greenhouses, interiorscapes, and conservatories feeding on a wide range of horticultural crops. However, mealybugs are difficult to regulate with insecticides as a result of the presence of a nearly impervious protective waxy covering, which means that alternative management strategies are required. As such, this study was designed to determine the value of applying silicon-based fertilizers such as potassium silicate to fiddleleaf fig, Ficus lyrata, plants as a means of alleviating outbreaks of the citrus mealybug, Planococcus citri. The study evaluated the effects of applying a commercially available silicon-based fertilizer product, ProTek ${ }^{\circledR}$ 0-0-3 The Silicon Solution, as a drench to the growing medium at different rates $(0,100,400,800$, and $1600 \mathrm{ppm}$ silicon). We determined the effect of the silicon-based fertilizer rate treatments on citrus mealybug life history parameters, including number of eggs laid by the female, body size ( $\mathrm{mm}$ ), and development time (days) from first instar to ovipositing adult female. In addition, we used a plant alkaline fusion technique to assess the concentration ( $\mathrm{mg} \cdot \mathrm{kg}^{-1}$ or $\mathrm{ppm}$ ) of silicon in the aboveground tissues (leaves and stems) of fiddleleaf fig plants at variable time intervals (days). This technique involves dry-ashing plant tissue in a muffle furnace followed by alkaline fusion and then colorimetric analysis. We found that the silicon-based fertilizer rate treatments did not negatively affect any of the citrus mealybug life history parameters measured. Citrus mealybug female egg load ranged from 132.3 to 159.2 and the development time (days) ranged from 66.9 to $68.7 \mathrm{~d}$. The silicon concentrations present in the fiddleleaf fig plants on the final harvest date were between 4419.2 and $7241.7 \mathrm{mg} \cdot \mathrm{kg}^{-1}$ silicon with fiddleleaf fig plants that received the 1600 ppm silicon-based fertilizer rate treatment having the highest silicon concentration. Moisture content was not significantly different among plants receiving the different silicon concentrations. Our results seem to suggest that fiddleleaf fig may actually be a silicon "rejector" and, as such, applications of silicon-based fertilizers are not beneficial to fiddleleaf fig plants because they do not accumulate sufficient quantities of silicon to impact citrus mealybugs.

\footnotetext{
Received for publication 11 June 2009. Accepted for publication 21 July 2009.

We thank Dr. Yoonseong Park in the Department of Entomology at Kansas State University (Manhattan, KS) for reviewing an initial draft of the manuscript. We also want to thank the five anonymous reviewers for their contributions.

${ }^{1}$ To whom reprint requests should be addressed; e-mail rcloyd@ksu.edu.
}

Mealybugs are major insect pests of interior plantscape environments such as greenhouses, interiorscapes, and conservatories feeding on a wide variety of horticultural plants (Blumberg and Van Driesche, 2001; James, 1937; Kole and Hennekam, 1990; McKenzie, 1967). The primary mealybug species encountered in greenhouses and conservatories is the citrus mealybug, Planococcus citri (Risso) (Barlett, 1978; Blumberg and Van Driesche, 2001; Cox, 1981; Malais and Ravensberg, 1992). Citrus mealybug is polyphagous, feeding on many horticultural crops such as Asparagus officinalis (L.), Dizygotheca elegantissima (Hort. Veitch), Euphorbia pulcherrima (Willd. ex Klotzsch), Impatiens walleriana (Hook. f.), Malus sylvestris (L.), Musa sp.; Rosa sp., Epipremnum aureum (Linden \& André), Codiaeum variegatum (L.), Aphelandra squarrosa Nees., Solenstemon scutellarioides (L.) Codd, and Ficus lyrata Warb. (Blumberg et al., 1995; Gray, 1953; MacGillivray, 1921; Malais and Ravensberg, 1992; McKenzie, 1967; Williams and Watson, 1988).

Citrus mealybug populations are typically controlled with either contact or systemic insecticides (Dreistadt, 2001; Hatting and Tate, 1997), which may quickly lower citrus mealybug populations to nondamaging levels and prevent future outbreaks from occurring (Hudson et al., 1996; Pedigo, 2002; Peleg and Bar-Zakay, 1995). However, managing citrus mealybug populations exclusively with insecticides is difficult because the third instar and adult females are covered with a hydrophobic, nearly impervious waxy coating that decreases penetration of contact insecticides through the cuticle, thus reducing efficacy (Copeland et al., 1985; McKenzie, 1967). As a result, routine applications of contact insecticides are needed early to avoid extensive citrus mealybug population outbreaks. If not detected in time, a citrus mealybug infestation may result in the presence of overlapping or simultaneous generations, thus making it difficult to manage citrus mealybug populations with insecticides, parasitoids, predators, lures, or traps.

The consequences of relying explicitly on insecticides have led to an increased interest in implementing other management strategies to deal with citrus mealybug populations (Hussey and Scopes, 1985). A potential strategy includes the appropriate use of fertilizers to prevent citrus mealybug population outbreaks (Fennah, 1959; Hogendorp et al., 2006). Furthermore, an analogous cultural practice involves applying supplemental fertilizers to enhance plant resistance to insect pests (Rojanaridpiched et al., 1984). As such, it has been suggested that applications of silicon may increase plant vigor and leaf epidermal toughness. In addition, silicon applications may act as an elicitor in triggering defensive processes in plants (Gomes et al., 2005; Heldt, 2005; Wadham and Parry, 1981).

Citrus mealybugs have piercing-sucking mouthparts, which are used to remove fluids from the phloem sieve tubes. Silicon-based fertilizer applications have been demonstrated to inhibit the feeding of piercingsucking insects (Salim and Saxena, 1992; Salim et al., 1990; Sōgawa, 1982) and stem borers (Djamin and Pathak, 1967; Nakano et al., 1961; Sasamoto, 1961; Ukwungwu, 1990).

Currently, there is minimal quantitative information associated with the use of silicon in preventing outbreaks of insect and/or mite pests of dicot plants grown in greenhouses. A number of studies have correlated increased 
silicon content in monocot plants such as rice and maize (Zea mays L.) with enhanced insect resistance (Djamin and Pathak, 1967; Moore, 1984; Rojanaridpiched et al., 1984; Salim and Saxena, 1992; Salim et al., 1990; Sharma and Chatterji, 1971; Sujatha et al., 1987; Ukwungwu, 1990). Moreover, additional studies have correlated applications of silicon-based fertilizers (as growing medium amendments or drenches) with increased insect resistance (Gomes et al., 2005; Moore, 1984; Sétamou et al., 1993; Wadham and Parry, 1981). However, relatively few studies have assessed applications of silicon-based fertilizers to dicot horticultural plants as a means of reducing feeding by piercingsucking insects (Hanisch, 1980; Moraes et al., 2005). It is possible that silicon-based fertilizer applications may impact insect feeding, negatively affecting life history parameters such as development time, fecundity, and reproductive rate. Therefore, the purpose of this study was to investigate the effects of applying a silicon-based liquid fertilizer at differing concentrations on the life history parameters, including egg load, size $(\mathrm{mm})$, and development time (days) of citrus mealybug when feeding on fiddleleaf fig, Ficus lyrata (Warb.), which is susceptible to this mealybug species.

\section{Materials and Methods}

This study was conducted to assess if applications of different rates $(0,100,400$, 800 , and 1600 ppm silicon) of a silicon-based fertilizer (as potassium silicate) would negatively impact the development and reproduction of citrus mealybugs feeding on fiddleleaf fig, Ficus lyrata, plants. We used a plant alkaline fusion technique followed by a colorimetric procedure to determine the concentration of silicon $\left(\mathrm{mg} \cdot \mathrm{kg}^{-1}\right)$ in the aboveground tissues of fiddleleaf fig plants associated with each application rate (Hogendorp, 2008). In brief, this technique involved determining the concentration of total silicon in the fiddleleaf fig plants (in triplicate) by dry-ashing the plant tissue in a muffle furnace (Hythermco, Pennsauken, $\mathrm{NJ}$ ) at $550{ }^{\circ} \mathrm{C}$ for a minimum of $4 \mathrm{~h}$ followed by alkaline fusion and colorimetric analysis. The concentration of total silicon was assessed using the reduced form of silicomolybdate measured at $820 \mathrm{~nm}$ on a spectrophotometer (Model 160; Shimadzu Corp., Kyoto, Japan) (Hogendorp, 2008).

Plant parameters. The study was set up as a completely randomized design using 75 fiddleleaf fig, Ficus lyrata (Warb.) (cv. Little Fiddle), plants that were obtained as rooted cuttings from AG3, Inc. (Eustis, FL) on 20 Feb. 2008. The rooted cuttings were transplanted into 15.4-cm standard pots (Dillen Products. Middlefield, OH) filled with Sunshine ${ }^{\circledR}$ LC1 growing medium (Sun Gro Horticulture $^{\odot}$ Canada Ltd.. Bellevue, WA), which was composed of $70 \%$ to $80 \%$ Canadian sphagnum peatmoss, perlite, dolomitic limestone, gypsum, and a wetting agent. The plants were grown in a greenhouse $(3.0 \times$ $6.0 \mathrm{~m}$ ) located inside the Plant Health Care
Facility at the University of Illinois (Urbana, IL) and placed on three $(1.4 \times 2.1 . \mathrm{m})$ raised wire-mesh benches. The temperature inside the greenhouse was maintained at $24 \pm 2{ }^{\circ} \mathrm{C}$ (day) and $22 \pm 2{ }^{\circ} \mathrm{C}$ (night), and all plants were subject to natural daylight conditions with no supplemental lighting.

Plants were irrigated with municipal water (Illinois American Water, Belleville, IL) for $14 \mathrm{~d}$ with no supplemental fertilizer to minimize transplant shock. On 5 Mar. 2008, the fiddleleaf fig plants received an initial fertilizer treatment without any supplemental silicon added using Peter's ${ }^{\circledR}$ 20N-8.8P16.6K (Scotts-Sierra Horticultural Products, Marysville, $\mathrm{OH})$ at $200 \mathrm{ppm}$ nitrogen. Twenty days later, on 25 Mar. 2008, all the plants received silicon treatments as potassium silicate (ProTek ${ }^{\circledR}$ 0-0-3 The Silicon Solution; Dyna-Gro Nutrient Solutions, Richmond, CA), which was incorporated with the nutrient solutions. There were five silicon-based fertilizer rate treatments $(0$, $100,400,800$, and 1600 ppm silicon) applied as a constant liquid feed with 15 plant replicates. The nutrient solutions that were mixed with the silicon-based fertilizer were prepared and maintained in $68.1-\mathrm{L}(61 \times 40 \times$ $42 \mathrm{~cm}$ ) storage tote reservoirs (Rubbermaid ${ }^{\circledR}$ Home Products, Wooster, OH). The nutrient solutions were initially prepared using Peter's ${ }^{\circledR} 20 \mathrm{~N}-8.8 \mathrm{P}-16.6 \mathrm{~K}$ at $200 \mathrm{ppm}$ nitrogen. Then, soluble potassium silicate was added to the reservoir resulting in the following treatment concentrations: $0,100,400$, 800 , and $1600 \mathrm{ppm}$ silicon. The composition of the potassium silicate fertilizer was $3.7 \%$ potassium (as $\mathrm{K}_{2} \mathrm{O}$ ) and $7.8 \%$ silicate (as $\mathrm{SiO}_{2}$ ) with a $2: 1$ weight ratio. Potassium sulfate was also incorporated into the silicon nutrient treatment solutions to compensate for the additional potassium. The concentrations of potassium sulfate added to each nutrient solution varied depending on the concentration of the potassium silicate treatment. The $0,100,400,800$, and 1600 ppm silicon treatments each received $64,62,48$, 32 , and $0 \mathrm{~g}$, respectively, of potassium sulfate incorporated into $56.7 \mathrm{~L}$ of nutrient solution. This ensured that the citrus mealybug responses to the silicon-based fertilizer treatments were not confounded by potassium. The final $\mathrm{pH}$ of the fertilizer treatment solutions for the treated and controls was 5.6 and 5.8, respectively, using concentrated sulfuric acid (Mallinckrodt Baker, Inc., Paris, $\mathrm{KY}$ ). The $\mathrm{pH}$ was measured with the aid of a pHTestr2 Double Junction pH meter (Oakton ${ }^{\circledR}$ Instruments, Vernon Hills, IL). Every $7 \mathrm{~d}$, the reservoirs containing the silicon treatment solutions were emptied and new treatment solutions were prepared so as to avoid the formation of silicon precipitates and gels. The fiddleleaf fig plants were watered as needed, receiving the applications of the silicon-based fertilizer treatments concurrent with the nutrient solutions. At each watering, plants were irrigated until leachate was observed.

On 9 May 2008, 45 d after the plants had received the first silicon treatment, a subset of five fiddleleaf fig plants from each treatment was harvested to determine the total silicon concentration using the plant alkaline fusion technique (Hogendorp, 2008). The mean values from the subset of plants were used to establish a baseline silicon concentration $\left(\mathrm{mg} \cdot \mathrm{kg}^{-1}\right)$ of the fiddleleaf fig plants for each treatment before artificially inoculating the plants with first instar citrus mealybugs through a coleus leaf disk procedure (described subsequently). At the conclusion of the study (7 July 2008), the remaining fiddleleaf fig plants were harvested and prepared for total silicon analysis using the plant alkaline fusion technique. Harvest procedures were accomplished by excising the plant stem at the level of the growing medium and removing the aboveground plant parts (leaves and stems) and storing the plant tissue in a \#20 brown paper bag (Commercial Bag and Supply, Des Moines, IA). Plant material was then weighed (in grams) within $2 \mathrm{~h}$ of processing and dried in a gravimetric convection oven (Precision Scientific Group, Chicago, IL) set at $62 \pm 2{ }^{\circ} \mathrm{C}$. The plant material was reweighed after 5 to $6 \mathrm{~d}$ in the gravimetric oven to determine dry matter content. Moisture content (in grams) was then assessed by subtracting the weight of the dry matter from the initial fresh weight.

Citrus mealybug parameters. Citrus mealybugs were reared on butternut squash, Cucurbita maxima (L.), in a growth chamber located in the National Soybean Research Laboratory, University of Illinois (Urbana, IL). The growth chamber was maintained at $24 \pm 5{ }^{\circ} \mathrm{C}$. On 9 May 2008, a coleus, Solenstemon scutellarioides (L.) Codd., leaf disk transport procedure was used to artificially inoculate the fiddleleaf fig plants with first instar citrus mealybug crawlers (Sadof et al., 2003). Coleus leaf disks $\left(1.7 \mathrm{~cm}^{2}\right)$ were excised from leaves obtained from stock plants and placed on top of the infested butternut squash for $\approx 30 \mathrm{~min}$. The coleus stock plants were located in the Plant Health Care Facility at the University of Illinois (Urbana, IL). Approximately 30 to 40 first instar citrus mealybug crawlers infested each leaf disk, which was positioned on the upper side of the first four leaves most adjacent to the apical bud of the plant. Five to six leaf disks were placed onto each fiddleleaf fig plant, resulting in between 150 and 240 first instar crawlers per plant. The leaf disks were allowed to remain on the fiddleleaf fig plants until they desiccated, which encouraged the first instar crawlers to migrate from the leaf disk onto the fiddleleaf fig leaves. The first instar crawlers are fragile and so it was important to minimize handling. Large initial populations were required to ensure collecting 15 mature ovipositing females from each fiddleleaf fig plant at the end of the study.

Two weeks after artificial inoculation, the fiddleleaf fig plants were inspected daily for the presence of ovipositing females and egg sac deposition. Oviposition was determined by the presence of a white cottony egg sac protruding from underneath the posterior portion of the abdomen. Once citrus mealybug 
females initiated oviposition, the body of the female, along with the corresponding egg sac, was collected using a microspatula. This made it possible to remove all the eggs contained within the egg sac and collect ovipositing females from difficult locations on plants such as petioles and branch junctions, resulting in nearly $100 \%$ recovery of all eggs. Fifteen ovipositing female citrus mealybugs were collected from each plant. In the event that there were less than 15 ovipositing females on the plants, then the maximum number of ovipositing females was collected.

Once the female body, along with the corresponding egg sac, was collected, they were transferred into a $20-\mathrm{mL}$ liquid scintillation glass vial (Research Products International Corp., Mount Prospect, IL) containing $\approx 15 \mathrm{~mL}$ of $70 \%$ isopropyl alcohol, which preserved the female citrus mealybug until the egg load and body size ( $\mathrm{mm}$ ) could be determined. The collection date of each citrus mealybug female was recorded to assess development time (days) from first instar crawler to ovipositing adult female. After collecting the citrus mealybugs from the fiddleleaf fig plants, the contents of the 20$\mathrm{mL}$ vial, including the body of the citrus mealybug female, corresponding egg sac, and any eggs in suspension, were quantitatively transferred to a small Pyrex ${ }^{\circledR}$ petri dish $(60 \times 15 \mathrm{~mm})$ (Corning Incorporated Life Sciences, Lowell, MA) and placed on the viewing stage of a Nikon SMZ1000 stereoscope (Nikon Instruments, Inc., Melville, NY). A metric ruler was placed beneath the small petri dish and the body length from the anterior portion to the caudal tip of the abdomen was measured $(\mathrm{mm})$ and recorded.

With the aid of a microprobe, the egg sac was separated from the body of each female and the eggs were removed from the egg sac. The body of the female was then positioned ventral-side down and dissected. All of the eggs were removed from within the body cavity. The $70 \%$ isopropyl alcohol aided the separation of the eggs from the waxy filaments covering the egg sac and the body cavity. Once all the eggs were in suspension, a grid was positioned beneath the small petri dish. The grid, consisting of thin black lines, was constructed and printed on a plastic overhead transparency ( $3^{\text {TM } M}$, Ontario, Canada) resulting in $\approx 1-\mathrm{cm}^{2}$ squares. This made it possible to demarcate the counted areas of the petri dish when using the Nikon SMZ1000 stereoscope making it possible to count all the eggs.

Data analysis. All data were analyzed using SAS systems for Windows, Version 9.1 (SAS Institute, 2002). The effects of the silicon-based fertilizer treatments on the citrus mealybug life history parameters, including female egg load, adult body size $(\mathrm{mm})$, and development time (days) from first instar crawler to ovipositing adult female, were analyzed using an analysis of variance procedure with the silicon-based fertilizer treatments (as potassium silicate) as the main effect. Fifteen ovipositing female citrus mealybugs were not always collected from each fiddleleaf fig plant; therefore, a different statistical test was needed. Significant treatment means were separated using a TukeyKramer least squares mean separation test adjusted for multiple comparisons. The Tukey-Kramer least squares mean separation test was used as a result of the variable number of ovipositing female citrus mealybugs collected from the fiddleleaf fig plants. A Fisher's protected least significant difference mean separation test was used to compare total fiddleleaf fig silicon concentration $\left(\mathrm{mg} \cdot \mathrm{kg}^{-1}\right)$ and plant moisture content $(\mathrm{g})$ within each harvest interval with the siliconbased fertilizer treatments as the main effect. Each treatment contained the same number of replications within each harvest interval and there were equivalent numbers of fiddleleaf fig replicates among the silicon-based fertilizer rate treatments.

\section{Results}

The effects of the silicon-based fertilizer rate $(0,100,400,800$, and $1600 \mathrm{ppm})$ treatments on the citrus mealybug life history parameters are presented in Table 1. There were no statistical differences among the silicon-based fertilizer rate treatments associated with female egg load $(F=1.57 ; \mathrm{df}=4$, $212 ; P=0.1845)$, size $(\mathrm{mm})(F=1.687 ; \mathrm{df}=$ 4, 212; $P=0.1559)$, and development time (days) $(F=1.57 ; \mathrm{df}=4,212 ; P=0.2401)$. The lowest mean female egg load occurred on plants treated with $0 \mathrm{ppm}$ silicon (132.3 eggs), whereas the highest mean female egg load was recorded on plants treated with 100 ppm silicon (159.2 eggs). There was a narrow range in mean female egg loads among all the silicon-based fertilizer rate treatments (132.3 to 159.2 eggs per female citrus mealybug) resulting in a difference of 26.9 eggs (Table 1). Mean development time of the citrus mealybugs occurred over a narrow range (66.9 to $68.7 \mathrm{~d}$ ), and all of the silicon-based fertilizer rate treatments were statistically similar to plants that received the $0 \mathrm{ppm}$ silicon treatment $(67.8 \mathrm{~d})$. Mean body size was between 2.20 ( $800 \mathrm{ppm}$ silicon) and 2.49 (100 ppm silicon) (Table 1), a difference of only $0.29 \mathrm{~mm}$.

There were significant differences in the total plant silicon concentrations $\left(\mathrm{mg} \cdot \mathrm{kg}^{-1}\right)$ associated with the silicon-based fertilizer rate treatments for the preinoculation harvest $(F=35.95 ; \mathrm{df}=4,24 ; P \leq 0.0001)$ with the highest silicon concentration $\left(6277 \mathrm{mg} \cdot \mathrm{kg}^{-1}\right)$ in plants that received $400 \mathrm{ppm}$ silicon and the lowest silicon concentration $(3775$ $\left.\mathrm{mg} \cdot \mathrm{kg}^{-1}\right)$ in fiddleleaf fig plants that received $0 \mathrm{ppm}$ silicon (Table 2). In the preinoculation harvest, the fiddleleaf fig plants that received any of the silicon-based fertilizer treatments $(100,400,800$, and $1600 \mathrm{ppm})$ were significantly different from the $0 \mathrm{ppm}$ silicon treatment. There were significant differences in silicon concentration $\left(\mathrm{mg} \cdot \mathrm{kg}^{-1}\right)$ associated with the silicon-based fertilizer rate treatments for the fiddleleaf fig plants in the second harvest $(F=18.39$; $\mathrm{df}=4,49 ; P \leq$ $0.0001)$. The lowest silicon concentration $\left(4419 \mathrm{mg} \cdot \mathrm{kg}^{-1}\right)$ was affiliated with fiddleleaf fig plants that received $0 \mathrm{ppm}$ silicon and the highest silicon concentration $\left(7241 \mathrm{mg} \cdot \mathrm{kg}^{-1}\right)$ was associated with those plants that received the $1600 \mathrm{ppm}$ silicon treatment (Table 2).

Although there were numerical differences in fiddleleaf fig moisture content (g) associated with the silicon-based fertilizer

Table 1. Mean ( \pm SEM) number for citrus mealybug (CMB), Planococcus citri, life history parameters, including number of eggs laid by female, body size ( $\mathrm{mm}$ ), and female development time (days), as a function of the potassium silicate fertilizer rate treatments to fiddleleaf fig, Ficus lyrata, applied as a growing medium drench. ${ }^{\mathrm{z}}$

\begin{tabular}{ccccc}
\hline $\begin{array}{l}\text { Fertilizer treatment } \\
\text { rate }(\mathrm{ppm})\end{array}$ & $\mathrm{n}$ & Mean \pm SEM & Mean \pm SEM & Mean \pm SEM \\
\hline 0 & 43 & $132.3 \pm 11.68 \mathrm{a}^{\mathrm{y}}$ & $2.3 \pm 0.10 \mathrm{a}$ & $67.8 \pm 0.62 \mathrm{a}$ \\
100 & 45 & $159.2 \pm 11.48 \mathrm{a}$ & $2.4 \pm 0.10 \mathrm{a}$ & $66.9 \pm 0.60 \mathrm{a}$ \\
400 & 42 & $149.1 \pm 11.84 \mathrm{a}$ & $2.4 \pm 0.10 \mathrm{a}$ & $68.5 \pm 0.63 \mathrm{a}$ \\
800 & 42 & $146.9 \pm 11.88 \mathrm{a}$ & $2.2 \pm 0.10 \mathrm{a}$ & $68.7 \pm 0.63 \mathrm{a}$ \\
1,600 & 41 & $152.0 \pm 12.00 \mathrm{a}$ & $2.2 \pm 0.11 \mathrm{a}$ & $68.0 \pm 0.62 \mathrm{a}$ \\
\hline
\end{tabular}

${ }^{{ }^{n}}=$ number of citrus mealybugs per silicon treatment rate. CMB eggs CMB body size (mm). CMB development time (days).

${ }^{y}$ Means followed by a common letter within a column are not significantly different $(P \leq 0.05)$ as determined by least square means separation test adjusted using Tukey-Kramer for multiple comparisons.

Table 2. Mean ( \pm SEM) silicon concentration $\left(\mathrm{mg} \cdot \mathrm{kg}^{-1}\right)$ of fiddleleaf fig, Ficus lyrata, plants associated with each harvest interval for the different silicon-based fertilizer rate treatment (ppm silicon). ${ }^{\mathrm{z}}$

\begin{tabular}{|c|c|c|}
\hline \multirow{2}{*}{$\begin{array}{l}\text { Silicon fertilizer rate } \\
\text { treatment }(\mathrm{ppm})\end{array}$} & Preinoculation $^{\mathrm{x}}$ harvest, 7 May & Second harvest, 7 July \\
\hline & Mean $\pm \operatorname{SEM}(n=5)$ & Mean \pm SEM $(n=10)$ \\
\hline 0 & $3,774.9 \pm 132.39 \mathrm{~b}^{y}$ & $4,419.2 \pm 220.97 \mathrm{c}$ \\
\hline 100 & $6,108.7 \pm 185.18 \mathrm{a}$ & $6,444.5 \pm 193.04 b$ \\
\hline 400 & $6,277.1 \pm 190.41 \mathrm{a}$ & $6,853.0 \pm 143.59 b$ \\
\hline 800 & $6,150.0 \pm 251.02 \mathrm{a}$ & $6,321.2 \pm 124.01 \mathrm{~b}$ \\
\hline 1,600 & $6,117.4 \pm 90.72 \mathrm{a}$ & $7,241.7 \pm 447.45 \mathrm{a}$ \\
\hline
\end{tabular}

${ }^{\mathrm{z}_{\mathrm{n}}}=$ number of plant replicates per treatment.

y Means followed by a common letter within a column are not significantly different $(P \leq 0.05)$ as determined by Fisher's protected least significant difference mean separation test.

xPlants were harvested before inoculation with first instar citrus mealybug crawlers using the coleus leaf disk procedure (Sadof et al., 2003). 
rate treatments in the preinoculation harvest, the differences were not statistically significant $(F=1.60 ; \mathrm{df}=4,24 ; P=0.2134)$ with the lowest and highest mean moisture contents ranging from 17.9 to $23.2 \mathrm{~g}$, a difference of only $5.3 \mathrm{~g}$ (Table 3 ). There were no significant differences in the fiddleleaf fig plants in regard to moisture content $(\mathrm{g})$ for the second harvest $(F=1.54 ; \mathrm{df}=4,24 ; P=$ 0.2068); however, plants that received 1600 ppm silicon had the lowest moisture content $(41.2 \mathrm{~g})$ for the second harvest.

\section{Discussion}

The silicon-based fertilizer rate treatments did not significantly affect any of the citrus mealybug life history parameters measured based on our results obtained for female egg load, adult size (mm), and development time (days) from first instar crawler to mature ovipositing female adult. This indicates that the silicon applications failed to produce any type of resistance in fiddleleaf fig plants to citrus mealybug feeding. These results are similar to those associated with citrus mealybug feeding on coleus and greenhouse whitefly feeding on poinsettia, Euphorbia pulcherrima Willd. ex Klotzsch, in which none of the silicon-based fertilizer treatments had any effect on either insect pest (Hogendorp, 2008). However, it has been well documented that concentrations of silicon in monocots such as rice and sugarcane leads to less injury from piercing-sucking insects (Salim and Saxena, 1992; Salim et al., 1990; Sōgawa, 1982) and stem borers (Djamin and Pathak, 1967; Meyer and Keeping, 2001; Nakano et al., 1961; Panda et al., 1975; Sasamoto, 1961; Sharma and Chatterji, 1971; Ukwungwu, 1990). The current study has demonstrated that fiddleleaf fig, which is a dicot, may be inherently different from agronomic monocot crops and does not benefit from supplemental siliconbased fertilizer applications.

The reason fiddleleaf fig was selected for our study was because of the premise that fiddleleaf fig absorbs a relatively high concentration of silicon (greater than $0.5 \%$ ) in aboveground tissues compared with other dicot plant species (Hodson et al., 2005; Lanning, 1966). A meta-analysis of 125 silicon-related studies reported a "high"

Table 3. Mean ( \pm SEM) moisture content ( $\mathrm{g}$ ) of fiddleleaf fig, Ficus lyrata, plants associated with each harvest interval for the different silicon-based fertilizer rate treatment (ppm silicon). ${ }^{\mathrm{z}}$

\begin{tabular}{|c|c|c|}
\hline \multirow{2}{*}{$\begin{array}{l}\text { Silicon fertilizer rate } \\
\text { treatment }(\mathrm{ppm})\end{array}$} & Preinoculation $^{x}$ harvest, 7 May & Second harvest, 7 July \\
\hline & Mean \pm SEM $(n=5)$ & Mean $\pm \operatorname{SEM}(n=10)$ \\
\hline 0 & $23.2 \pm 1.38 \mathrm{a}^{\mathrm{y}}$ & $49.3 \pm 2.86 \mathrm{a}$ \\
\hline 100 & $19.6 \pm 1.74 \mathrm{a}$ & $52.6 \pm 5.23 \mathrm{a}$ \\
\hline 400 & $17.9 \pm 2.10 \mathrm{a}$ & $49.5 \pm 3.30 \mathrm{a}$ \\
\hline 800 & $20.3 \pm 0.92 \mathrm{a}$ & $52.2 \pm 3.84 \mathrm{a}$ \\
\hline 1,600 & $19.2 \pm 1.37 \mathrm{a}$ & $41.2 \pm 2.64 \mathrm{a}$ \\
\hline
\end{tabular}

${ }^{\mathrm{z}} \mathrm{n}=$ number of plant replicates per treatment.

${ }^{y}$ Means followed by a common letter within a column are not significantly different $(P \leq 0.05)$ as determined by Fisher's protected least significant difference mean separation test.

xPlants were harvested before inoculation with first instar citrus mealybug crawlers using the coleus leaf disk procedure (Sadof et al., 2003).

mean relative shoot silicon concentration [1.728 (residual maximum likelihood)] for fiddleleaf fig, ranking from 648 of 735 total plant species, which is a relatively high ranking among dicots and doubling the average mean relative shoot silicon concentration Rosales plant order $[\approx 0.780$ (residual Lanning (1966) reported a silica deposition value of $3.0 \%$ in fiddleleaf fig leaves; however, the initial classification or ranking of fiddleleaf fig as a possible "neutral" plant may have been arbitrary.

The potassium silicate fertilizer rate treatments resulted in significant differences in silicon concentrations in fiddleleaf fig tissues both harvest intervals in which fiddlelea based fertilizer rate treatments appeared to absorb and accumulate more silicon than those plants that received $0 \mathrm{ppm}$ silicon. It has been suggested that deposits of silicon polymers in the intracellular and intercellular spaces, vascular elements, and on the surface of leaf tissues are associated with increased insect resistance (Keeping and Meyer, 2002; Ma and Takahashi, 2002; Sangster and Hodson, 1986; Sangster and Perry, 1981; Savant et al., 1997; Sétamou et al., 1993; Yoshida et al., 1962), although in our study, elevated silicon concentrations in the aboveground tissues of fiddleleaf fig did not negatively affect any of the citrus mealybug life history parameters measured: female egg load, adult size (mm), and development time (days).

In the second harvest, untreated fiddleleaf fig plants had silicon concentrations (4419 $\left.\mathrm{mg} \cdot \mathrm{kg}^{-1}\right)$ in the tissues that would classify them as silicon "rejectors" (Ma et al., 2001) although fiddleleaf fig plants that received supplemental silicon-based fertilize treatments accumulated sufficient concenrations (6321 to $7241 \mathrm{mg} \cdot \mathrm{kg}^{-1}$ ) of silicon to classified as silicon "neutral," that is, plants containing silicon concentrations from 5,000 to $30,000 \mathrm{mg} \cdot \mathrm{kg}^{-1}$ (Ma et al., 2001). lated half of the siliso plants only accumutissues when compared with cucumber, Cucumis sativus L. plants (13,000 to 19,000 $\mathrm{mg} \cdot \mathrm{kg}^{-1}$ ) (Miyake and Takahashi, 1983). Again, this suggests that fiddleleaf fig may actually be a silicon "rejector" plant.

It is interesting to note that the differences between the highest and lowest silicon con-

HortScience Vol. 44(6) October 2009 centrations in fiddleleaf fig plants associated with the preinoculation harvest were more narrow $\left(2502 \mathrm{mg} \cdot \mathrm{kg}^{-1}\right)$ compared with the differences detected in the silicon concentrations in the second harvest $\left(2822 \mathrm{mg} \cdot \mathrm{kg}^{-1}\right)$. Fiddleleaf fig plants that received the 1600 ppm silicon-based fertilizer rate treatment had the highest silicon concentration (7241 $\mathrm{mg} \cdot \mathrm{kg}^{-1}$ ); however, this silicon concentration did not appear to inhibit citrus mealybug feeding or restrict access to essential nutrients for development and reproduction. Correa et al. (2005) reported that silicon applications attributed to increased nymphal mortality of sweetpotato whitefly B-biotype (Bemisia tabaci Gennadius) feeding on cucumber. It is possible that the threshold silicon concentration value for providing silicon-mediated host-plant resistance to insect pests with piercing-sucking mouthparts is between 7,300 and $19,000 \mathrm{mg} \cdot \mathrm{kg}^{-1}$ silicon.

Most studies that evaluate the effect of silicon applications on certain insect pests involve monocots, and, in general, monocots accumulate substantially more silicon in plant tissues than dicots (Jones and Handreck, 1967; Sangster and Hodson, 1986). It has been suggested that the roots of monocot plant species such as oat, Avena sativa (L.), may contain several large pore (protein) pathways that allow water movement into the symplast, coupled with uncharged nonelectrolytes such as monosilicic acid, which is distributed through mass flow (Jones and Handreck, 1965; Raven, 1983).

In a study using a dicot plant, Ranger et al. (2009) found that higher concentrations of silicon were present in Zinnia elegans Jacq. plants treated with potassium silicate compared with untreated plants; however, the length of the prereproductive period and survivorship of the green peach aphid, Myzus persicae (Sulzer), were not negatively affected and total cumulative fecundity and intrinsic rate of increase was marginally reduced when feeding on plants that received soluble silicon. Similar to our study, this demonstrates that silicon applications may not benefit dicot plants in terms of reducing outbreaks of insect pests.

Fiddleleaf fig plants, being a long-lived woody perennial, may be able to continually accumulate and increase silicon concentrations in aboveground plant tissues over time. However, it may be that the duration of the our study was too short with silicon concentrations being assessed 105 and $136 \mathrm{~d}$ after plants had received the silicon-based fertilizer rate treatments. As such, additional studies investigating the effects of silicon accumulating in fiddleleaf fig tissues over an extended time period involving multiple or overlapping generations of citrus mealybug may be warranted.

Although our study did not assess where silicon was deposited in fiddleleaf fig tissues, observations indicated that citrus mealybugs preferred to feed on new, young, succulent leaf tissue with relatively few citrus mealybugs harvested from fully expanded mature leaves and petioles (B. Hogendorp, personal 
observation). Silicon is transported and deposited through the transpiration stream leading to increased silicon deposition in older plant tissues, thus resulting in a thicker leaf epidermis (Marschner, 1995). Lanning (1966) determined fiddleleaf fig leaves contain $1.5 \%$ silicon in leaf tissues, although the leaf age was not reported. Furthermore, the midribs of fiddleleaf fig leaves, where citrus mealybugs tend to feed, contain significantly lower silicon concentrations $(0.16 \%)$ when compared with the other leaf portions (Lanning, 1966). As such, it is possible that silicon concentrations were not accumulating in the tissues preferred by citrus mealybug, but in older tissues, which may explain why they preferred the younger tissues. It is reasonable to assume that citrus mealybugs were not inhibited from accessing essential nutrients for development and reproduction despite the concentrations of silicon in the fiddleleaf fig leaves.

The silicon-based fertilizer rate treatments resulted in silicon accumulating in aboveground plant tissues; nonetheless, these concentrations were insufficient to promote any sort of plant resistance. Our results are in contrast to other studies involving agronomic monocot crops and cucumber plants. Minimal information exists supporting the hypothesis associating silicon applications to greenhouse-grown dicot crops with siliconmediated plant resistance. This study has demonstrated that regardless of silicon concentration, there was no effect on citrus mealybugs feeding on fiddleleaf fig in terms of inhibiting development and reproduction. As such, it may be warranted to reclassify fiddleleaf fig as a silicon "rejector."

\section{Literature Cited}

Barlett, B.R. 1978. Pseudococcidae, p. 137-170. In: Clausen, C.P. (ed.). Introduced parasites and predators of arthropod pests and weeds: A world review. USDA-ARS Agric. Handbook, No. 480. U.S. Department of Agriculture, Washington, DC.

Blumberg, D., M. Klein, and Z. Mendel. 1995. Response by encapsulation of four mealybug species (Homoptera: Pseudococcidae) to parasitization by Anagyrus pseudococci. Phytoparasitica 23:157-163.

Blumberg, D. and R.G. Van Driesche. 2001. Encapsulation rates of three encyrtid parasitoids by three mealybug species (Homoptera: Pseudococcidae) found commonly as pests in commercial greenhouses. Biol. Control 22: 191-199.

Copeland, M.J., C.C. Tingle, M. Saynor, and A. Panis. 1985. Biology of glasshouse mealybugs and their predators and parasitoids, p. 82-86. In: Hussey, N.W. and N. Scopes (eds.). Biological pest control. Cornell University Press, Ithaca, NY.

Correa, R.S., J.C. Moraes, A.M. Auad, and G.A. Carvalho. 2005. Silicon and acibenzolar-Smethyl as resistance inducers in cucumber, against the whitefly Bemisia tabaci (Gennadius) (Hemiptera: Aleyrodidae) biotype B. Neotrop. Entomol. 34:429-433.

Cox, J.M. 1981. Identification of Planococcus citri (Homoptera: Pseudococcidae) and the description of a new species. Syst. Entomol. 6:47-53.
Djamin, A. and M.D. Pathak. 1967. Role of silica in resistance to Asiatic rice borer, Chilo suppressalis Walker in rice varieties. J. Econ. Entomol. 60:347-351.

Dreistadt, S.H. 2001. Knowing and recognizing mealybugs and scale insects, p. 207-211. In: Flint, M.L. (ed.). Integrated pest management for floriculture and nurseries. University of California Statewide Integrated Pest Management Project. Division of Agriculture and Natural Resources Publication 3402, Oakland, CA.

Fennah, R.T. 1959. Nutritional factors associated with the development of mealybugs in cacao. Rep. Cacao Res. Inst., Trinidad. p. 18-28.

Gomes, F.B., J.C. Moraes, C. Donizete dos Santos, and M.M. Goussain. 2005. Resistance induction in wheat plants by silicon and aphids. Sci. Agr. (Piracicaba, Braz.) 62:547-551.

Gray, H.E. 1953. Physiological studies on the nutrition of the mealybug Pseudococcus citri (Risso) (Homoptera: Coccidae). PhD Diss., University of Illinois, Champaign-Urbana, IL.

Hanisch, H.C. 1980. Zun einfluss der stickstoffdungung und vorbeugender spritzung von natronwasser glas zu weizenpflazen auf deren widerstandsfahifkeit gegen getreideblattlause. Kali-Driefe 15:287-296.

Hatting, V. and B.A. Tate. 1997. The pest status of mealybugs on citrus in South Africa, p. 560 563. In: Manicom, B., J. Robinson, S.T. Plessis, P. du Joubert, J.L. Zyl, and S. van du Preez (eds.). Proc. International Soc. Citric, Sun City. International Soc. Citric, Nelspruit, Republic of South Africa.

Heldt, H.W. 2005. Phenylpropanoids comprise a multitude of plant secondary metabolites and cell wall components, p. 435-454. Plant biochemistry, Elsevier, San Diego, CA.

Hodson, M.J., P.J. White, A. Mead, and M.R. Broadley. 2005. Phylogenetic variation in the silicon composition of plants. Ann. Bot (Lond.) 96:1027-1046.

Hogendorp, B.K. 2008. Effects of silicon-based fertilizer applications on the development and reproduction of insect pests associated with greenhouse-grown crops. PhD Diss., University of Illinois, Urbana-Champaign, IL.

Hogendorp, B.K., R.A. Cloyd, and J.M. Swiader. 2006. Effect of nitrogen fertility on reproduction and development of citrus mealybug, Planococcus citri Risso (Homoptera: Pseudococcidae), feeding on two colors of coleus, Solenostemon scutellarioides L. Codd. Environ. Entomol. 35:201-211.

Hudson, W.G., M.P. Garber, R.D. Oetting, R.F Mizell, A.R. Chase, and K. Bodari. 1996. Pest management in the United States greenhouse and nursery industry: I. Trends in chemical and nonchemical control. HortTechnology 6:194 200.

Hussey, N.W. and N. Scopes. 1985. Biological pest control: The glasshouse experience. Cornell University Press, Ithaca, NY.

James, H.C. 1937. Sex ratios and the status of the male in Pseudococcidae (Hem. Coccidae). Bull. Entomol. Res. 28:429-461.

Jones, L.H. and K.A. Handreck. 1965. Studies of silica in the oat plant. Plant Soil 23:79-96.

Jones, L.H. and K.A. Handreck. 1967. Silica in soils, plants, and animals. Adv. Agron. 19:107-149.

Keeping, M.G. and J.H. Meyer. 2002. Calcium silicate enhances resistance to sugarcane to the African stalk borer Eldana saccharina Walker (Lepidoptera: Pyralidae). Agr. For. Entomol. 4:265-274.

Kole, M. and M. Hennekam. 1990. Update: Six years of successful biological control in interior plantscapes in The Netherlands. The IPM Practitioner 12:1-4.

Lanning, F.C. 1966. Silica and calcium deposition in the tissues of certain plants. Adv. Frontiers Plant Sci. 13:55-66.

Ma, J.F., Y. Miyake, and E. Takahashi. 2001. Silicon as a beneficial element for crop plants, p. 17-40. In: Datnoff, L.E., G.H. Snyder, and G.H. Korndörfer (eds.). Silicon in agriculture. Elsevier, Amsterdam, The Netherlands.

Ma, J.F. and E. Takahashi. 2002. Soil, fertilizer, and plant silicon research in Japan. Elsevier, Amsterdam, The Netherlands.

MacGillivray, A.D. 1921. The coccidae. Scarab Company, Urbana, IL.

Malais, M.H. and W.J. Ravensberg. 1992. Knowing and recognizing - The biology of glasshouse pests and their natural enemies. Reed Business Information, Doetinchem, The Netherlands.

Marschner, H. 1995. Mineral nutrition of higher plants. Academic Press, London, UK.

McKenzie, H.L. 1967. Mealybugs of California. University of California Press, Los Angeles, CA.

Meyer, J.H. and M.G. Keeping. 2001. Past, present and future research of the role of silicon for sugarcane in southern Africa, p. 257-276. In: Datnoff, L.E., G.H. Snyder, and G.H. Korndörfer (eds.). Silicon in agriculture. Elsevier, Amsterdam, The Netherlands.

Miyake, Y. and E. Takahashi. 1983. Effect of silicon on the growth of cucumber plant in soil culture. Soil Sci. Plant Nutr. 29:463-471.

Moore, D. 1984. The role of silica in protecting Italian ryegrass (Lolium multiflorum) from attack by dipterous stem-boring larvae (Oscinella frit and other related species). Ann. Appl. Biol. 104:161-166.

Moraes, J.C., M.M. Goussain, G.A. Carvalho, and R.R. Costa. 2005. Feeding non-preference of the corn leaf aphid Rhopalosipum maidis (Fitch, 1856) (Hemiptera: Aphididae) to corn plants (Zea mays L.) treated with silicon. Ciência e Agrotecnologia 29:761-766.

Nakano, K., G. Abe, N. Taketa, and C. Hirano. 1961. Silicon as an insect-resistance component of host plant, found in relation between the rice stem-borer and the rice plant. Jap. J. Appl. Entomol. Zool. 5:17-27.

Panda, N., B. Pradhan, A.P. Samalo, and P.S. Rao. 1975. Note on the relationship of some biochemical factors with the resistance in rice varieties to yellow rice borer. Indian J. Agr. Sci. 45:499-501.

Pedigo, L.P. 2002. Conventional insecticides, p. 381-440. In: Entomology and pest management. Prentice Hall, Upper Saddle River, NJ.

Peleg, B.A. and I. Bar-Zakay. 1995. The pest status of citrus scale insects in Israel (1984-1994). In: Ascher, K.R. and Y. Ben-Dov (eds.). Proc. VII International Symp. on Scale Insect Studies. Bet Dagan, Israel

Ranger, C.M., A.P. Singh, J.M. Frantz, L. Cañas, J.C. Locke, M.E. Reding, and N. Vorsa. 2009. Influence of silicon on resistance of Zinnia elegans to Myzus persicae (Hemiptera: Aphididae). Environ. Entomol. 38:129-136.

Raven, J.A. 1983. The transport and function of silicon in plants. Biol. Rev. Camb. Philos. Soc. 58:179-207.

Rojanaridpiched, C., V.E. Gracen, H.L. Everett, J.G. Coors, B.F. Pugh, and P. Bouthyette. 1984. Multiple factor resistance in maize to European corn borer. Maydica 29:305-315.

Sadof, C.S., J.J. Neal, and R.A. Cloyd. 2003. Effect of variegation on stem exudates of coleus and life history characteristics of citrus mealybug 
(Hemiptera: Pseudococcidae). Environ. Entomol. 32:463-469.

Salim, M. and R.C. Saxena. 1992. Iron, silica, and aluminum stresses and varietal resistance in rice: Effects on whitebacked planthopper. Crop Sci. 32:212-219.

Salim, M., R.C. Saxena, and M. Akbar. 1990. Salinity stress and varietal resistance in rice: Effects on whitebacked planthopper. Crop Sci. 654-659.

Sangster, A.G. and M.J. Hodson. 1986. Silica in higher plants, p. 90-111. In: Evered, D. and M. O'Connor (eds.). Silicon biochemistry. John Wiley \& Sons, Chichester, Sussex, UK.

Sangster, A.G. and D.W. Perry. 1981. Ultrastructure of silicon deposits in higher plants, p. 383407. In: Simpson, T.L. and B.E. Volcani (eds.). Silicon and siliceous structures in biological systems. Springer-Verlag, New York, NY.

SAS Institute. 2002. SAS/Stat user's guide, version 9.1. SAS Institute, Inc., Cary, NC.
Sasamoto, K. 1961. Resistance of the rice plant applied with silicate and nitrogenous fertilizers to the rice stem borer, Chilo suppressalis Walker. Proc. Faculty of Liberal Arts Education 3. Yamanashi University, Japan.

Savant, N.K., G.H. Snyder, and L.E. Datnoff. 1997. Silicon management and sustainable rice production. Adv. Agron. 58:151-199.

Sétamou, M., F. Schulthess, N.A. Boque-Pérez, and A. Thomas-Odjo. 1993. Effect of plant nitrogen and silica on the bionomics of Sesamia calamistis (Lepidoptera: Noctuidae). Bull. Entomol. Res. 93:405-411.

Sharma, V.K. and S.M. Chatterji. 1971. Studies on some chemical constituents in relation to differential susceptibility of some maize germplasms to Chilo zonellus (Swinhoe). Indian J. Entomol. 33:419-424.

Sogawa, K. 1982. The rice brown planthopper: Feeding physiology and host plant interactions. Annu. Rev. Entomol. 27:49-73.
Sujatha, G., G.P. Reddy, and M.M. Krishna-Murthy. 1987. Effect of certain biochemical factors on the expression of resistance of rice varieties to brown planthopper (Nilaparvata lugens Stal.). J. Res. APAU. 15:124-128.

Ukwungwu, M.N. 1990. Host plant resistance in rice to the African striped borer, Chilozacconius Bles. (Lepidoptera: Pyralidae). Insect Sci. Appl. 11:639-647.

Wadham, M.D. and D.W. Parry. 1981. The silicon content of Oryza sativa L. and its effect on the grazing behaviour of Agriolimax reticulates Müller. Ann. Bot. (Lond.) 48:399-402.

Williams, D.J. and W.G. Watson. 1988. The scale insects of the tropical and South Pacific region, part 2. The Mealybugs (Pseudococcidae). CAB International, Wallingford, Oxon, UK.

Yoshida, S., Y. Hnishi, and K. Kitagishi. 1962. Chemical forms, mobility, and deposition of silicon in the rice plant. Japan. J. Soil Sci. Plant Nutr. 8:107-111. 